\title{
Graduate Students' Perspective about the MA TEFL Program at Hashemite University in Jordan
}

\author{
Mohammed M. Obeidat ${ }^{1} \&$ Malak M. Shehadeh ${ }^{2}$ \\ ${ }^{1}$ Faculty of Educational Sciences, The Hashemite University, P.O. Box 330127, Zarqa 13133, Jordan \\ ${ }^{2}$ Jordan International Schools, P.O Box 188, Amman 11821, Jordan \\ Correspondence: Mohammed M. Obeidat, Faculty of Educational Sciences, The Hashemite University, P.O. Box \\ 330127, Zarqa 13133, Jordan
}

Received: December 30, 2019

Accepted: February 2, 2020

Online Published: February 6, 2020

doi:10.5430/ijhe.v9n3p28

URL: https://doi.org/10.5430/ijhe.v9n3p28

\begin{abstract}
This current study aimed to investigate MA students' perspectives about the English as a foreign language (EFL) curriculum and methods of teaching program employed in the Department of Curriculum and Instruction at the Hashemite University. More specifically, the study attempted to explore the students' perspectives of the program in terms of strengths and weaknesses. Data was collected through a questionnaire interview from 9 students who were about to finish their study. Findings showed that students highlighted the instructional and research-skill benefits for the program. They also revealed that the main weak points of the program were related to theory or theoretical orientation, statistics, the professor's behavior, and research project. The findings can be valuable for teaching English as a foreign language (TEFL) syllabus designers, TEFL instructors, instructors of other subject areas, and researchers in higher education.
\end{abstract}

Keywords: graduate students, perspective, MA TEFL programs, the Hashemite University in Jordan

\section{Introduction}

\subsection{ESL/EFL Master Degree Programs}

Master in English as a second language (ESL) or in teaching English as a second or foreign language (TESOL) programs normally prepare graduates to work with adults who do not speak English as their first language. Students in these programs have the opportunity to understand better the way in which people learn languages, and study advanced teaching methods and assessment strategies to help others develop English proficiency. Most ESL or TESOL master programs combine classroom instruction with practicum components to provide students with sufficient and efficient experience Whereas ESL Masters programs focus on teaching within English speaking communities, teaching English as a foreign language (TEFL) masters programs are those allotted to teach in communities where English is not the first language. With regard to outcome, programs offering a master degree in English education equip new and experienced teachers with the skills and subject-area experience to improve student literacy through literature and writing (Grad Schools, 2019). However, ESL curriculum and instruction programs aim to help an ESL graduate understand how to teach students of varying educational levels. In general, the master degree program usually takes 2-3 years to complete, during which the student will learn the way in which cultural dynamics can be understood, language abilities can be developed, social skills can be fostered, and curricula can be created (Learn, 2019).

There are many well-known English as a foreign language (EFL) master degree programs both in developed and developing countries. As for developed countries, many programs were developed in Europe and the United States of America. The British Council developed many courses in English language teaching (ELT). One of them is the master degree in ELT, which was developed collaboratively by the University of Southampton and the British council. It offers postgraduate-level study in areas related to current theory and practice in applied linguistics and English language teaching. The course was developed by an experienced team of e-tutors through an online distance learning environments. The program structure includes two years of taught modules and final semester spent undertaking research and writing dissertation (British Council, 2014). In Spain, a program was developed to train professionals to teach English for both general and specific purposes. This program is a combination of professional 
and research tracks, and it was designed for national and international graduates, with or without experience, who wish to work professionally in the field of English language teaching (URV, 2019).

ESL is an essential subject in the United States. It may benefit more than one million immigrants. English language teachers might also consider pursuing an ESL or TESOL certificate master program. They should have an interest in languages and a passion for helping others learn new cultures. They may assist language learners through ESL methods, or teach English to learners in other countries through TEFL programs. Finally, they should understand the basic concepts of learning languages. Therefore, TESOL master programs explore these concepts, and may improve communication skills and build leadership qualities to better guide EFL students into fluency (Best Colleges, 2018).

In general. MA nominees or applicants learn about ESL education in terms of methodology, curriculum design, research practices and instructional theory. Having an MA degree in this field can help graduates to work in primary, secondary or postsecondary schools, as well as international or overseas companies. The curriculum for MA programs in ESL teaching prepares teachers for the complexities of language instruction. Many programs blend or combine mentored teaching experiences that provide practical classroom training. The common courses normally include: (1) Introduction to English education. (2) Methods for ESL teaching. (3) Curriculum development in ESL education. (4) Theories in second language acquisition. (5) ESL writing and literature education. (6) Issues in ESL education (Study, 2019).

There are many EFL master degree programs in the Arab Word. The majority of them follow the American system. One of these programs, which is relatively similar to that adopted in Jordan, is in Oman. It includes two types of TESOL/TEFL program: course work and thesis or course work only. The duration of this program is 2-year full-time and three-year for part-time. In terms of the courses and thesis track, the student should complete 8 courses ( 24 credit hours) and thesis ( 6 credit hours) in the first year for full-time students and in two years for part-time students. As for the course only track, the student should complete 12 courses (36 credit hours) in three semesters for full-time students and four semesters for part-time students. Before starting the program, the admitted candidates should submit an English Proficiency Test Certificate band (6), or higher in a candidate international English Language Testing or a score (79), or higher in the international TOEFL-IBT (Master Studies, 2020).

We notice from the literature above that TEFL or TESOL master degree programs not only focus on ELT methods but also on current theory and practice in general. In addition, These programs emphasize other educational issues, such as curriculum design and research practices.

\subsection{The Master Degree Program at the Hashemite University}

The MA TEFL program in the Hashemite University is somewhat similar to those developed in the Jordanian public universities. However, This program has two tracks adopted for obtaining the master degree in the English language curriculum and methods of teaching at the university. The first track is the courses only track and the second is the courses and thesis track. These tracks are taught by instructors of different specializations, which are general curriculum and instruction, EFL curriculum and instruction, psychology and educational management. However, with respect to the first track, its syllabus includes compulsory and optional courses. The compulsory courses are (1) English language instruction (1), (2) English language instruction (2), (3) Evaluation of English language learning and teaching, (4) Error analysis, (5) Curriculum planning and development, (6) Research project, (7) Advanced psychology, and (8) Analytic statistics. The optional courses are (1) Applied linguistics, (2) First and second language acquisition, (3) Teacher education and supervision, (4) Special issues and topics in teaching the English language, and (5) Contemporary trends in the English language curriculum. In terms of the second track, the plan also encompasses compulsory and optional courses. The compulsory courses comprise (1) English language instruction (1), (2) English language instruction (2), (3) Evaluation of English language learning and teaching, (4) Error analysis, (5) Advanced psychology, (6) Analytic statistics, and (7) Research project. The optional ones include (1) Curriculum planning and development, (2) Applied linguistics, (3) Advanced psychology, (4) First and second language acquisition, (5) Teacher education and supervision, (6) Special issues and topics in teaching the English language, and (7) Contemporary trends in the English language curriculum.

The description of the courses are as follows:

English language instruction (1): This course covers language and pedagogic concepts related to teaching in Jordan and the various theories associated with acquiring language skills.

English language instruction (2): This course is concerned with analyzing English language teaching and its relationship with teaching trends associated with the teacher, book, student and curriculum. 
Evaluation of English language learning and teaching: This course is interested in the basic concepts of evaluation, types of evaluation, forms of evaluation, alternative evaluation and the psychometric properties of the test.

Error analysis: This course discusses compelling theories in analyzing the goals of reading and writing, their applications and their use in planning curricula to reduce linguistic errors.

Curriculum planning and development: This course covers curriculum theories, forms of curriculum theories, curriculum types and curriculum ideologies.

Research project: This course includes preparing a mini-research in the field of student's specialization and preparing a comprehensive research report between 5000-10.000 words.

Advanced psychology: This course deals with various areas related to educational psychology and its theories, contemporary theories of learning and their applications and influencing issues in the educational learning process, such as motivation, intelligence, creative and critical thinking patterns, and learning difficulties.

Analytic statistics: This course deals with the use of appropriate statistical analysis to examine hypotheses and the use of SPSS.

Applied linguistics: This course discusses the relationship between the principles of theoretical linguistics and its applications in teaching and learning EFL. It also discusses various applied linguistic trends in teaching the English language.

First and second language acquisition: This course discusses theories of first and second language acquisition., and general strategies for acquiring different languages.

Special issues and topics in teaching the English language: This course deals with a number of issues related to teaching EFL, such as using the first language in teaching and learning the second language and dealing with classes of multiple levels of achievement and compatibility between theory and practice.

Contemporary trends in the English language curriculum: This course covers the fundamentals of the curriculum, its design, its types and its evaluation. It also covers the social, political, economic and cognitive dimensions of the English language curriculum.

Teacher education and supervision: This course examines the current and historical framework for teacher preparation, the various models in teacher preparation, the current trends in the field of teaching supervision and the reciprocal relations between the teacher and supervisor.

\subsection{The Purpose and Questions of the Study}

The purpose of this study is to investigate MA students' perspectives about the EFL curriculum and methods of teaching program employed in the Department of Curriculum and Instruction at the Hashemite University. All in all, the study attempts to answer the following research questions:

A. What are the major benefits students gain from the EFL curriculum and methods of teaching program?

B. What are the weaknesses of this program as viewed by the students?

\section{Review of Related Studies}

Graduate students' perspectives about the programs developed for them are of paramount importance. The reason lies in the fact that the majority have prior knowledge, beliefs and experience in the field. For example, Akbari and Karimi (2013: 1) defined personal epistemology as "a person's implicit beliefs and assumptions regarding the nature, acquisition, structure, sources, and justification of knowledge...". They added that this type of knowledge is of vital importance in predicting learners' beliefs, behaviors and academic outcomes in different fields of education. The researchers concluded that the concept personal epistemology has been ignored in ELT in general. As a result, this current study attempts to shed light on the available literature related to MA students' perspectives about the programs they attended with regard to benefit and weakness.

Awang, et al. (2013) explored contributing factors to students' attitudes towards the subject Malaysian study. The researchers employed a quantitative approach through which four main factors were categorized, including the suitability and interest in syllabus, being active in class, early preparation and revision, types of enjoyable activities, and interest in teaching aids and good classroom attendances. They used a questionnaire and SPSS as the main instruments of the study. Findings indicated that students' perception of their lectures played a significant role in 
determining their attitudes and learning outcomes, while the lecturers' opinion was that learning environment was a factor which contributed a lot to the students' achievement in this subject.

Ithaka College (2015) made interviews with many postgraduate students. The purpose was to differentiate between the pedagogic behaviors of college professors and high school teachers. One of the students remarked, "High school teachers are often on a tight schedule with a fully day of back-to-back classes. Therefore, they don't have time to make appointments with students to talk about problems or questions. Professors don't usually have back-to-back classes, so they have the time to have office hours and encourage students to stop in and talk to them about what is going on". Another student argued, "It may be sound weird that college professors 'know' when you are absent, but it's scarily true...college professors definitely know when you are not there". A third student commented, "High school teachers typically let you know everything you missed, give you the assigned readings. Professors expect you to look online to see what readings you may have missed as well as get the detailed notes from another student". The college asked the students the question Do you think professors check out their students?, and one of the students remarked, "Of course professors check out their students. They are still human beings. They don't inhibit your ability to find people attractive, regardless of if they're your students or not". In terms of the relationship between the professor and his or her students, Lyons (2011) argued, "If you're one student in a class of hundreds or only have a professor once during all of your college years, the chances are your only interaction with your teachers will be brief and impersonal. But if instead you're in a small class or have the same professor for multiple classes, like ones in your major, you might have the opportunity to get to know them on a deeper level. This could be through classroom interaction office hours meeting or may be even just while running into another on campus" (P. 1).

Emaliana (2017) investigated EFL postgraduates' and undergraduates' attitudes toward student-centered and traditional teaching approaches, culture learning in EFL program, attitudes toward authority in class, the main problems encountered in the course in learning English and their practice of language learning strategies. The data was collected through a questionnaire, following Xiao's (2006). The findings of this study provided EFL teachers with thoughtful information about students' learning needs as an input to syllabus and material planning, lesson planning and classroom instruction practice. They also shed light on the importance of a good understanding of students' variables in TEFL programs at the university level in Indonesia.

Pray and Daniel (2018) state that the Master of Education (M.ED.) in English language learning is open to students who already hold a teaching license or who wish to pursue advanced study in teaching linguistically diverse students in international settings. The main goal is to gain basic and practical information the student needs to effectively serve those who are learning English as a second or foreign language. The Clemson Master of Education in teaching and learning, for example, prepares the student to advance his or her professional study in eighteen (18) months. Several interviews were made with the students who were studying in the College of Education. One of them remarked, "The program really pushes you to identify who you are as an educator and what areas that you need to grow in. I benefit both professionally and personally, and the program helps me to achieve better outcomes for my students" (Clemson University, 2019: p.1).

The Master level curriculum and instruction program in Southwestern College has the student ready for career progression in education. Learners normally choose from many areas of emphasis and learn from experienced education professionals who bring rich knowledge and expertise to the actual classroom setting. Learners are provided with the tools and flexibility needed to succeed in their education while preparing for professional advancement. One of the graduates from this college in 2015 argued, "I looked at different colleges to begin my program....Southwestern was one of the colleges that transferred most of my previous college work with me and that's why I chose Southwestern" (Southwestern, 2019: p.1).

In an article written by Clemente (2019) on how faculty and academic departments could prepare students for the world of work, the syllabus was emphasized. The researcher argued that it is a crucial document in which career readiness could be integrated. He also argued that a skill objective should be considered. Clemente added that the career readiness competences identified by the National Association of Colleges and Employees (NACE) are skills, which ought to be acquired in the course. They are critical thinking, oral skills and written communication, teamwork or collaboration, information technology approach, leadership, professionalism and work ethic, career management and global or multi-cultural fluency.

Farrah (2019) conducted a qualitative study whose aim was to investigate MA students' perceptions regarding an MA TEFL practicum course at Hebron University. The students expressed a number of aspects on how the course contributed to their professional development. Findings showed that the most effective aspect as perceived by the students was micro-teaching that emphasized the importance of integrating theory and practice. They also revealed 
that the second effective aspect was classroom observation. One of the students argued, "Observing actual language classes...was very beneficial as it helped me to write observational reports as well as achieving better teaching performance". In addition, the findings showed that the third and fourth aspects which contributed to the participants' professional growth were successively planning and reflective practice. Finally, these findings indicated that the fifth aspect in the course that promoted students' professional growth was classroom management and collaborative work.

University of Birmingham (2020) also made many interviews with postgraduate students during 2019 about full-time distance learning courses. For example, Yue expressed her mind about the full-time courses she attended, arguing, "I really appreciated that teaching took place in very small groups which meant that I felt relaxed to take part in discussions, which my supervisor was very patient and provided very useful advice on my writing. My course combined theory and practice together, while giving me lots of opportunities to present my ideas to my classmates".

It is apparent to the reader that there are few experimental, quasi-experimental, or qualitative studies done in this area in higher education. The majority of these studies conducted here and there were executed by some colleges and/or universities, which attempted to elicit students' views about some courses, programs or syllabuses. Therefore, the current study has come to the scene to fill a gap in the national and international literature with regard to Master's degree students' views about the effectiveness (i.e., benefits and weaknesses) of the program allotted to MA TEFL curriculum and methods of teaching in the Jordanian teaching-learning context in higher education. This may benefit all those interested in TEFL programs and programs in other educational areas at the graduate and postgraduate levels.

\section{Methods}

A qualitative case study approach was employed to investigate MA students' perspectives about the EFL curriculum and methods of teaching program developed by the Department of Curriculum and Instruction in the Faculty of Educational Sciences at the Hashemite University. Due to the problems in English language education in general and in English language teaching methodology in particular, eliciting students' views about this program can be regarded as an opportunity to know more about it in terms of strengths and weaknesses. The focus will not only be on the specialized courses, but also on everything related to the program, depending on the nature of students' responses to the open-ended questions. Therefore, the cases in this study may help TEFL syllabus designers, TEFL Instructors, and instructors of compulsory and optional courses in the Faculty of Educational Sciences to gain insight into the benefits students gain from the target program and into the weak points they highlight for the purpose of making further modifications and/or changes. This may also help TEFL syllabus designers and practitioners in other teaching-learning contexts in higher education for them to make remedies in their MA programs. Finally, this study may open up new paths of research for the purpose of improving TEFL programs with regard to content, method, and personal or pedagogic behaviors of instructors.

\subsection{The Setting and Participants of the Study}

This current study was executed in the Department of Curriculum and Instruction at the Hashemite University. All of the students selected for the interview were in their second year of MA study. These students were the participants of the study. The total number of EFL students was 11. For the purpose of the study, 9 were chosen to be interviewed.

\subsection{Data Collection and Analysis}

Data was collected through a questionnaire interview, which comprised two open-ended questions. Face-to-face interviews were avoided in order for each student to have the freedom and time to answer these questions frankly and objectively. However, the open-ended questions were sent through students' E-mails. They were requested to think and rethink deeply of the questions for them to answer each in detail. The two open-ended questions are the same as those stated in the purpose of the study, which are (1) What are the major benefits you get from the EFL curriculum and methods of teaching program? (2) What are the weak points of the program you think they need remedial measures?. The data were analyzed through the use of thematic analysis. That is, the researchers followed five steps to carry out this kind of analysis. They are: First, they listed the responses to each question; second, they read and reread these responses thoroughly to discover particular themes for them; third, they formulated themes for each set of responses; fourth, they categorized or grouped them according to the themes they were related to; and fifth, they quoted each set of responses next to each theme and then tabulated them for the purpose of clear presentation. 


\section{Results}

\subsection{Results Related to the First Research Question}

One fundamental finding of the study is that six of the interviewees highlighted the instructional or professional benefits for the MA program. These benefits are related to teaching methods, classroom management, evaluation, and research skills. Three of them stated that the program benefited them in terms of the contemporary methods of teaching included in English language instruction (1) and English language instruction (2). Below are illustrative examples of students' responses.

....English language Instruction (2) deepened my knowledge of communicative language teaching and the eclectic way of teaching adopted by the English language curricula in the Ministry of Education.

This program improved my English language and acquainted me with the contemporary approaches to language teaching, particularly the communicative approach. This has helped me to deal with the activities included in the Basic Education Stage.

I really benefited from the subjects "English language Instruction 1", "English language Instruction 2" and.... The first two subjects have helped in my career....

Two of the interviewees declared that the program developed their skill of classroom management and the way in which they could deal with their students: see the examples below.

Of course, I benefited from the MA program. It helped to know how to deal with my pupils in the class. In other words, they have become more active and more responsive....

I benefited from the seminar forms used in some of the lectures in the program. They helped me to manage the class in my school. My students have become cooperative through group- or pair-work. The subject "classroom planning and development" benefited me a lot in this respect.

One of the interviewees reported that the program enriched their knowledge of evaluating students' achievement. As he states:

I benefited from the program in my profession as a classroom teacher. It enriched my knowledge of language learning and teaching. It also shed light on the way I can evaluate my students' achievement. The subject "Evaluation of English language learning and teaching" benefited me a lot.

Another important finding of the study is associated with research-skill benefits. Five of the interviewees stated that the program developed their skill of research in order to write the MA or PhD thesis professionally: See the examples below.

....The main subjects I benefited from are: research project.... The research project acquainted me with the research skills....

I really benefited from the subjects.... and "Research project". ....and the third will help me to deal well with my thesis and research in the future.

In addition, the program improved my skill in research, particularly in terms of documentation and questionnaire development.

I benefited from the research skills provided by my professor in the subject "Research project". I have become knowledgeable in dealing with references in and at the end of study. I have also become knowledgeable of the requirements of developing theses.

The most important benefit is related to research skills. This has helped me to write my MA AND PhD theses in the future. I have the aspiration to be a doctor at the university.

Table 1 illustrates the themes and interviewees' responses to the first research question. 
Table 1. The benefits the students get from the EFL curriculum and methods of teaching program

\begin{tabular}{|c|c|}
\hline Category & Students' views \\
\hline \multirow[t]{6}{*}{$\begin{array}{c}\text { Instructional/Professional } \\
\text { benefits }\end{array}$} & $\begin{array}{l}\text { S1 ....English language Instruction (2) deepened my knowledge of } \\
\text { communicative language teaching and the eclectic way of teaching adopted by } \\
\text { the English language curricula in the Ministry of Education. }\end{array}$ \\
\hline & $\begin{array}{l}\text { S2 I benefited from the program in my profession as a classroom teacher. It } \\
\text { enriched my knowledge of language learning and teaching. It also shed light } \\
\text { on the way I can evaluate my students' achievement. The course "Evaluation } \\
\text { of English learning and teaching" benefited me a lot. }\end{array}$ \\
\hline & $\begin{array}{c}\text { S3 This program improved my English language and acquainted me with the } \\
\text { contemporary approaches to language teaching, particularly the } \\
\text { communicative approach. This has helped me to deal with the activities } \\
\text { included in the Basic Education Stage, }\end{array}$ \\
\hline & $\begin{array}{l}\text { S4 I really benefited from the courses "English language Instruction 1", } \\
\text { "English language Instruction 2" and... The first two courses have helped in } \\
\text { my career... }\end{array}$ \\
\hline & $\begin{array}{l}\text { S5 Of course, I benefited from the MA program. It helped to know how to deal } \\
\text { with my pupils in the class. In other words, they have become more active } \\
\text { and more responsive.... }\end{array}$ \\
\hline & $\begin{array}{l}\text { S7 I benefited from the seminar forms used in some of the lectures in the } \\
\text { program. They helped me to manage the class in my school. My students have } \\
\text { become cooperative through group- or pair-work. The course "classroom } \\
\text { planning and development" benefited me a lot in this respect. }\end{array}$ \\
\hline \multirow[t]{5}{*}{ Research-skill benefits } & $\begin{array}{l}\text { S1 ....The main course I benefited from are: research project..... The research } \\
\text { project acquainted me with the research skills.... }\end{array}$ \\
\hline & $\begin{array}{l}\text { S4 I really benefited from the courses.... and "Research project". .....and the } \\
\text { third will help me to deal well with my thesis and research in the future. }\end{array}$ \\
\hline & $\begin{array}{l}\text { S5 ....In addition, the program improved my skill in research, particularly in } \\
\text { terms of documentation and questionnaire development. }\end{array}$ \\
\hline & $\begin{array}{c}\text { S6 I benefited from the research skills provided by my professor in the course } \\
\text { "Research project". I have become knowledgeable in dealing with references } \\
\text { in and at the end of study. I have also become knowledgeable of the } \\
\text { requirements of developing theses. }\end{array}$ \\
\hline & $\begin{array}{l}\text { S9 The most important benefit is related to research skills. This has helped me } \\
\text { to write my MA AND PhD theses in the future. I have the aspiration to be a } \\
\text { doctor at the university. }\end{array}$ \\
\hline
\end{tabular}

\subsection{Results Related to the Second Research Question}

The analysis of interviewees' responses to the second research question what are the weak points of the program you think they need remedial measures? led to four main themes. These themes are associated with the theoretical orientation of the program, statistics, the professor's behavior, and the research project. In terms of theoretical orientation, five of the interviewees stated that they suffered a lot from it, particularly in the courses curriculum planning and development, error analysis, and psychology. Some of them suggested solutions to solve this problem: as stated in the examples below:

Some of the courses such as curriculum planning and development and psychology were not beneficial. Curriculum planning and development focused on theory rather than practice and psychology was repetitive to psycholinguistics.

The majority of the courses included in the program were theoretical. Even the course "Error analysis" focused on theory, and by the end of the semester, the professor gave us an assignment to apply this theory. Therefore, the professors should give us step by step assignments. 
Some of the course emphasized theory. This means that the faculty should either cross these courses out from the program or changes their plans.

Two of the interviewees stated that the main weakness of the program is statistics. They complained about the instructors who taught the course "Analytic statistics" and reported that they thought students were good at statistics or at mathematics in general: see the examples below.

The main weak point is the course "Analytic Statistics". I did not get the benefit from any topic in this course. The professor thought we were good at statistics and mathematics in general.

My problem is statistics. When the instructor gave me an assignment to apply what she said, I used not to answer any question. The instructors was always in rush in answering the examples.

Two of the interviewees complained about the pedagogic and social behaviors of some professors. One of them stated that some of the professors were bias and another declared that some were not responsive. As stated in the examples below:

I worked hard in this program but some of the professors were bias with some of the students. They focused on females and left me without a reasonable total grade average.

The main weak point is that some of the teachers were not responsive. If you try to ask them a question either in the classroom or in the office, their response is 'I have no time...I have another lecture with a frown.

One of the interviewees stated that the weakness of the program lies in the course 'Research project' and its instructor. That is, the instructor was useful for students who would write their theses in Arabic: see the example below.

The weak point of the program is the subject "Research project". My specialization is English language teaching methods and the teacher who gave this subject does not know English well. He benefited only the students whose specialization required writing the thesis in Arabic.

Table 2 illustrates the themes and interviewees' responses to the second research question. 
Table 2. The weak points of the program students think they need remedial measures

\begin{tabular}{|c|c|}
\hline \multirow[t]{5}{*}{ Theoretical orientation } & $\begin{array}{l}\text { S1 Some of the courses, such as curriculum planning and development and } \\
\text { psychology, were not beneficial. Curriculum planning and development focused } \\
\text { on theory rather than practice and psychology was repetitive to } \\
\text { psycholinguistics. }\end{array}$ \\
\hline & $\begin{array}{l}\text { S3 The majority of the courses included in the program were theoretical. Even } \\
\text { the course "Error analysis" focused on theory, and by the end of the semester, } \\
\text { the professor gave us an assignment to apply this theory. Therefore, the } \\
\text { professors should give us step by step assignments. }\end{array}$ \\
\hline & $\begin{array}{l}\text { S4 I suffered a lot from theory in most of the courses in the program. This } \\
\text { theory is not applicable in the Jordanian context. Some of the instructors talked } \\
\text { about issues three hours without a break. }\end{array}$ \\
\hline & $\begin{array}{l}\text { S6 ....I have had a problem with theory in most of the courses in the program. } \\
\text { This theory is not applicable in the Jordanian context. }\end{array}$ \\
\hline & $\begin{array}{l}\text { S8 Some of the courses emphasized theory. This means that the faculty should } \\
\text { either cross these courses out from the program or changes their plans. }\end{array}$ \\
\hline \multirow[t]{3}{*}{ Statistics } & $\begin{array}{l}\text { S2 The main weak point is the course "Analytic Statistics". I did not get the } \\
\text { benefit from any topic in this course. The professor thought we were good at } \\
\text { statistics and mathematics in general. }\end{array}$ \\
\hline & S4 ....I also suffered from statistics because my mind is not scientific. \\
\hline & $\begin{array}{l}\text { S9 My problem is statistics. When the instructor gave me an assignment to } \\
\text { apply what she said, I used not to answer any question. The instructors was } \\
\text { always in rush in answering the examples. }\end{array}$ \\
\hline \multirow[t]{2}{*}{ The professor's behavior } & $\begin{array}{l}\text { S5 I worked hard in this program but some of the professors were bias with } \\
\text { some of the students. They focused on females and left me without a reasonable } \\
\text { total grade average. }\end{array}$ \\
\hline & $\begin{array}{l}\text { S6 The main weak point is that some of the teachers were not responsive. If you } \\
\text { try to ask them a question either in the classroom or in the office, their response } \\
\text { is 'I have no time...I have another lecture with a frown. }\end{array}$ \\
\hline The research project & $\begin{array}{l}\text { S7 The weak point of the program is the course "Research project". My } \\
\text { specialization is English language teaching methods and the teacher who gave } \\
\text { this course does not know English well. He benefited only the students whose } \\
\text { specialization required writing the thesis in Arabic. }\end{array}$ \\
\hline
\end{tabular}

\section{Discussion}

The purpose of this current study was to investigate MA TEFL students' perspectives about the EFL curriculum and methods of teaching program implemented at the Hashemite University. That is, the study attempted to explore a sample of students' views about this program in terms of benefit and weakness.

With regard to benefit, findings indicated that the program benefited the students instructionally or professionally, particularly in the areas relevant to current teaching methods, classroom management and evaluation. They also revealed that this program developed their research skills. The findings associated with the instructional or professional benefits cohere with what was argued by (Grad Schools, 2019) that master in ESL or in TESOL programs give students the chance to study advanced teaching methods and assessment strategies to help others develop language proficiency. They also equip new and experienced teachers with the skills and subject-area experience to improve student literacy. The findings also agree with what was stated by (Learn, 2019) that one job of an ESL graduate may be to understand how to teach students of varying educational levels. One of the interviewees in Clemson University (2019) declared that he benefited from the M.ED program both personally and professionally. With respect to the benefit gained from the research-skill, it is a matter of fact for the students to say that the program benefited them in this regard. The reason lies in the fact that knowledge of methodology can be obtained from various resources, but research-skill needs training and close supervision. It is also a matter of fact that the main difference between undergraduate and graduate courses is research. In addition, most of the MA programs adopted in 
developed and developing countries include research practice and thesis or dissertation writing (Study, 2019, URV, 2019, \& Master studies, 2020).

As for the weakness of the program, the interviewees complained about the theoretical orientation of some of the courses. They also suffered from statistics or the course "Analytic statistics" and from the lack of responsiveness of some of the professors. The interviewees' complaints about the theoretical orientation counter the findings obtained by (Emaliana, 2017), which revealed that the program provided EFL students with thoughtful information about students' learning needs as an input to syllabus and material planning, lesson planning and classroom instruction practice. These complaints were not also in line with the findings obtained by (Farrah, 2019) that the course developed in Hebron University emphasized micro-teaching, classroom observation, planning, reflective practice, classroom management and collaborative work. These aspects helped students promote their professional growth. In addition, the interviewees' viewpoint does not agree with what was declared by one of the students who attended a full-time learning course in the University of Birmingham (2020). He appreciated the group-work and discussion techniques which took place during the course, and the combination of theory and practice together. In terms of some professors' pedagogic and social behaviors seen by our interviewees, the students in Ithaka College (2015) showed different viewpoints. One of them argued that professors usually had time to have office hours and they normally encouraged students to stop in and talked to them about what was going on. Another remarked that professors are human beings and they did not inhibit the student's ability to find people attractive. With respect to statistics or to the course "Analytic statistics", it is a matter of fact to say that the students would suffer from it since the majority of them were not in the scientific stream both at the school and university levels. Concerning the student who complained about the course "research project", s/he has the right to complain about it since it is normally given to the students of different specializations.

\section{Conclusion}

The findings of the present study were limited to the setting and the interviewed participants . However, this study provides important implications for TEFL syllabus designers, TEFL instructors, and instructors of general education courses in order to make necessary modifications or even changes in the MA programs. It also encourages researchers in TEFL to conduct studies in other higher education institutions for each study to complement the other.

It seems that students' perspectives at the MA level are of paramount importance and they can be regarded as a key for modification, development or change. Therefore, policy-makers, EFL syllabus designers and instructors should take their perspectives into account. Moreover, researchers concerned with EFL education at the graduate level ought to conduct studies which use both quantitative and qualitative research methods so that the qualitative results can support the quantitative.

\section{Acknowledgement}

I would like to give my sincere and deep gratitude to Professor Ali AbuSeileek for his valuable comments on the present research study. I would also like to thank all of the interviewees who contributed to the development of this study.

\section{References}

Akbari, R. \& Karimi, M.N. (2013). EFL Students' Proficiency Outcomes: What do Epistemological Beliefs have to Offer? Asian EFL Journal, 15(3), 10-37. Researchgate.net/publication/286167483

Awang, M., Ahmed, A., Abu-bakr, N., Ghani, S., Yunus, A., Ibrahim, M., Ramalu, J., Saad, C. \& Rahman, M. (2013). Students' Attitudes and their Academic Performance in Nationhood Education. International Education Studies, 6(11), 21-28. http://dx.doi.org/10.5539/ies.von11p21

Best colleges (2018). Master's in ESL. http://www.bestcolleges.com/features/masters-esl-programs/

Clemente, I. (2019). Integrating Career Readiness into your courses. American Psychological Association's: Psych Learning Curve. Psychlearningcurve.org/integrating=caree-readiness-into-your-courses

Clemson University (2019). Master of Education: Teaching and Learning. College of Education, 102 Tillman Hall, Clemson, $\quad$ SC 29634.0702. clemson.edu/education/academics/masters-specialist-programs/masters-education-teaching-learning/index.html

Emaliana, I. (2017). Teacher-Centered or Student-Centered Learning Approach to Promote Learning. Jurnal Sosial Humaniora, 10(2), 59-70. http://dx.doi.org/10.12962/j24433527

Grand Schools (2019). Master in ESL \& TESOL Graduate Programs. Gradschools.com/masters/esl-tesol 
Farrah, M. (2019). MA TEFL Students' Reflection on a Practicum Course: A Qualitative Study. The Qualitative Report, 24(9), 2332-2350. Retrieved from http://nsuworks.notva.edu/tqr/viewcontent.cgi?article=3441\&context=tqr

Ithaca College, K.J. (2015). College Professors Versus High School Teachers: The Differences between the two Kinds of Educators. Odyssey. Theodysseyonline.com/college-professors.vs.high-school-teachers

Learn, org. (2019). ESL Curriculum and Instruction Master's Degree. Learn.org/articles/ESL_curriculum_and_instruction_Masters_Degree.html

Lyons, J. (2011). Should Professors and Students be Friends? Education Insider NewsBlog. Studycom/articles/Is-it-a-Good-Idea-for-Professors-and-Students-to-Be-Friends.html

Master Studies (2020). Master's Programs in Oman. Masterstudies.com/Masters-Degree/Oman/Muscat/

Pray, L. \& Daniel, S. (2018). Master of Education (M.Ed.) in English Language Learners. Department of Teaching and Learning. Peabody.vanderbilt.edu/programs/english-language-learner-med/

Southwestern (2019). Master of Education Curriculum and Instruction. Southwestern College Professional Studies. Ps.sckans.edu/degrees-and-certificates/masters-degrees/master-of-education-curriculum-and-instruction/

Study (2019). Masters Degrees in ESL Teaching: Program Overviews. http://study.com/masters_degrees_in_esl_teaching.html

University of Birmingham (2020). MA Teaching English to Speakers of Other Languages (TESOL) (Distance Learning). Birmingham.ac.uk/postgraduate/courses/distance/English/English-foreign-second-lang-aspx

URV (2019). Master in Teaching and Learning English as a Foreign/Second Language. http://www.masterstudies.com 